\title{
Student Teachers' Microteaching Experiences in a Preservice English Teacher Education Program
}

\author{
Sadiq Abdulwahed Ahmed Ismail \\ United Arab Emirates University, United Arab Emirates \\ Email: Ism232@gmail.com
}

\begin{abstract}
Microteaching has been widely used in pre-service teacher education programs to enhance prospective teachers' instructional experiences. Within ELT programs, the use of microteaching offers valuable opportunities for trainee-teachers to develop effective teaching strategies. Understanding the perceptions and concerns of student teachers is crucial for promoting teacher education programs' outcomes. This study aimed at investigating the views of sixty-one female teacher trainees from the English Language Education Program in the Faculty of Education in the United Arab Emirates University (UAEU) regarding the microteaching component offered in two courses of English language teaching methods. A combination of quantitative and qualitative techniques was employed for the purpose of gathering the data. Mainly, a questionnaire and a focus group interview were used as the main tools for data collection. Overall analysis of the findings indicated that prospective teachers described a variety of benefits they gained from microteaching experiences. The study ended with recommendations and directions for future studies to further examine the highlighted results.
\end{abstract}

Index Terms —education, English, trainee, microteaching, preservice, method

\section{INTRODUCTION}

This paper highlighted the salient benefits of microteaching as prospective teachers perceive them. It was also the purpose of this paper to show that microteaching has the potential to impact trainee teachers' beliefs and attitudes. Within the traditional 'theory/practice dichotomy', there has always been an assumption that student teachers will be able to transfer the pedagogical theories and approaches they learned in universities to their future classes in schools (Kubukcu, 2010; Fernandez and Robinson, 2007; Johnson, 2006). However, a formal practical training, such as the use of microteaching, may assist in bridging the gap between theory and practice. A microteaching program provides preservice teacher-trainees with a simulated situation to put the theories that they have learned into practice and to develop confidence and teaching skills while conducting a mini-lesson to their colleagues. Microteaching is also intended to provide teacher trainees with additional practical experience before they start their clinical practice in real classes. Microteaching was introduced in the 1960s at the Stanford Teacher Education Program in Stanford University to prepare students for their internships (Cruickshank et al., 1996). The original model was cyclical in nature since it involved 'plan, teach, observe, critique' followed by the repetition of the same steps after the whole process was reviewed (Bell, 2007; Amobi, 2005). The microteaching model was found to help student teachers learn about and reflect upon different teaching procedures that they have been exposed to in the methods of teaching classes. Some students consider microteaching as 'fake teaching' since it does not involve real students in a real teaching situation where a teacher and students interact naturally. Bell (2007) argued that microteaching provides students with valuable teaching experiences and made them aware of the benefits and relationships between theories and practice.

Researchers recommend searching for and adopting applications and experiences that provide student teachers with opportunities to be involved in exploring pedagogical experiences, self-reflection and critical analysis of teaching (Fernandez, 2010; Putnam \& Borko, 2000). Grossman and McDonald (2008) indicated that such opportunities allow student teachers to experiment with aspects of practice and then learn from that experience. Microteaching application is considered a suitable approach to meet the above-mentioned recommendations. In the present study, the microteaching application in the two methods of teaching courses was designed to provide students with practical experiences after they had been exposed to different approaches and techniques for teaching ESL classes. It was, therefore, intended to prepare students for their 'practice teaching' in elementary schools. By conducting microteaching, students would try the ideas they learned with their colleagues before they started using them in real classes. The microteaching component along with the lesson planning and self-reflection made-up $30 \%$ of the students' course grade.

\section{PROBLEM STATEMENT}

Microteaching application has gained popularity as a practical training tool in pre-service teacher education programs. Ever since its emergence in the 1960s, the practice of microteaching has rapidly widespread in different parts of the world, including the Middle East. In the present pre-service ELT teacher education program in the Faculty of Education, United Arab Emirates University (UAEU), it makes up about 30\% of the total time and grade of all methods of teaching 
courses. In those courses, students have to plan and conduct mini-lessons to their peers. Self-reflection and giving feedback are integral components of the microteaching practices. A number of student teachers seem to enjoy this experience while others struggle to get through the whole process of practicing to learn how to teach. Hence, it is vital to conduct a thorough investigation to find out about the learners' views about the application of microteaching in their program of study. Ultimately, the findings of this study will assist course instructors to review the program and meet students' needs and expectations.

\section{RESEARCH QUESTIONS}

1. How does microteaching impact ESL student teachers' views about language improvement and course satisfaction?

2. How do ESL student teachers perceive microteaching to impact their teaching competence?

3. How do ESL student teachers view microteaching in relation to their managerial and preparation skills?

4. What kind of attitude or feeling do student teachers hold about the practice of microteaching?

\section{LITERATURE REVIEW}

The major goal of a successful teacher-training program is to expose prospective teachers to effective teaching strategies and experiences. The place of microteaching in teacher education programs has been examined for a number of years by researchers in different parts of the globe (Fernandez, 2010; Lu, 2010; Ogeyik, 2009, Seferoglu, 2006; Subramaniam, 2006; Amobi, 2005; Akalin, 2005; Higgins and Nicholl, 2003; Wilkinson, 1996). During the 1960s, microteaching was first introduced in a teacher education program in Stanford University to prepare students and get them ready for their clinical experiences (Cruickshank et al., 1996). Since its introduction in the 1960s, the practice of microteaching has rapidly expanded to other teacher education programs. Recently, many pre-service teacher education programs have introduced the microteaching component in order to orient prospective teachers and provide them with practical teaching experiences (Fernandez, 2010; Bell, 2007; Amobi, 2005). The endorsement of microteaching as a tool for learning the art of teaching attracted a number of educators and researchers to investigate its impact on prospective teachers' teaching experiences and how they perceive it as a practical learning tool.

In a relevant study, Ogeyik (2009) investigated the attitudes of 57 ELT teacher trainees at Trakya University in Turkey regarding the benefits and disadvantages of microteaching. A five-scale questionnaire was used to survey students' opinions about microteaching applications. The overall findings demonstrated the students' positive attitudes towards microteaching applications in their study program. They found microteaching to be beneficial for both their academic study and professional experience. The author concluded that the use of microteaching in a teacher-training program could promote effective teaching strategies and reflective practices among student teachers.

In a similar study, Benton-Kupper (2001) looked at prospective teachers' perceptions about the application of a microteaching component in a methodology course. After completing the microteaching sessions, student teachers in three sections of a general secondary methods course reflected on their practical experiences and provided quantitative and qualitative feedback on the use of microteaching. The findings of the study indicated that the microteaching practice is very beneficial for prospective teachers to learn about the craft of teaching. Trainee teachers indicated that they found microteaching experiences helpful in enabling them to recognize and identify strengths and weaknesses in their mini lessons. The study provided evidence that the microteaching component is an effective training tool in teachers' preparation programs.

Fernandez (2010) investigated how and what teacher trainees learn about teaching from microteaching lesson study (MLS). The researcher carried out a case study of MLS with 18 student teachers in a course of math teaching methods. Different research tools were used to collect extensive data. These multiple data sources helped in triangulating the findings. During the different phases of the study, videotape and audiotape were used to record the MLS lessons and the group discussion respectively. During the MLS experiences, students were able to explore, analyze, plan and revise their lessons; additionally they participated as learners in other students' lessons. After being exposed to the MLS, prospective teachers were able to explore patterns and develop effective strategies for teaching mathematics. The MLS was found to be an effective teaching approach because it offers prospective teachers valuable opportunities to practice and learn teaching during their initial coursework. It was indicted that student teachers were able to identify general teaching patterns and classroom management issues during the MLS lessons though they were teaching their colleagues and were acting in a "fake" situation.

In an earlier study, Fernandez and Robinson (2007) investigated the perceptions of 74 student teachers at Florida State University about MLS. Four different sections of teacher trainees in an initial course of mathematics teaching methods participated in the study. Similar to the above-mentioned study, the students in this research overwhelmingly expressed that the opportunity to apply in practice the pedagogical theories they learned in the course was extremely beneficial. They indicated that they had spent a lot of time talking about theories while they needed the chance to try the theories and get feedback on their actual performance. Within the MLS lessons, trainee teachers had an opportunity to plan lessons and try the different teaching strategies that they had been exposed to in their study in the program. At the end, student teachers appreciated other people's views and feedback about their teaching performance and they acknowledged the great benefits of reflection in learning the art of teaching. 
In a study of peer coaching, Britton and Anderson, (2010) investigated the influence of peer coaching on classroom teaching practices of pre-service student teachers. The study was conducted in a high school in a southeastern region of the United States with about 1900 students from different groups in grades 9-12. Four student teachers agreed to participate in the study after they had learned peer coaching. Participants observed each other's classes, collected data and carried out conferences with one another. Findings revealed that participants had positive views about peer coaching as they saw it as a simple process to teach and easy to learn. Participants also found peer coaching useful because it provided them with opportunities to observe and communicate with their colleagues. It was found that peer coaching assisted in altering and developing teaching practices. Data also revealed that peers enjoyed this 'stress free' experience of listening to their colleagues' comments as compared to observations by university or classroom supervisors. Support for the findings of this study was reported by Lu's (2010) review of peer coaching literature from 1997-2007. Lu also reported that peer coaching was found to be beneficial in pre-service programs as it helps student teachers develop professionalism. Although not technically called microteaching, peer coaching utilizes the same strategies of learning from one's colleagues.

Microteaching experiences may not be as effective without offering prospective teachers opportunities to reflect on their performance. The goal of any successful pre-service teacher education program is to prepare effective and reflective teachers. Novice student teachers in a training program always possess preconceptions about teaching. Those students have the experience of sitting in classes for a number of years observing instructors teaching them with a variety of teaching methods. Thus, it is very crucial for teacher-trainers to listen to the preconceptions of prospective teachers and help them promote effective teaching strategies (Amobi and Irwin, 2009). The use of reflection strategies provides educators with an opportunity to correct any misconception that might interfere while student teachers are practicing effective teaching strategies. Reflective practices, such as critically observing a video-recorded lesson can offer valuable opportunities for student teachers to revisit their executed lessons and make thoughtful decisions for improvement and develop effective teaching strategies.

Amobi (2005) examined the reflective outputs of 31 secondary education pre-service teachers during a second microteaching session. The study focused on the recurrent themes of reflectivity of self- and peer-evaluations. The study featured mini lessons taught to colleagues, a videotape used to record lessons, a ready-made form used for writing feedback and oral reports on the experience. All trainees were expected to submit between one to two pages of selfreflection focusing on what they initially intended to do, what they did and how they would do it differently. During the discussion sessions, students were invited to confront their peers' feedback and comments on their mini lessons. The overall findings of the study demonstrated more defensive and passive patterns than affirmative patterns. The researcher concluded that student teachers considered microteaching as a favorable and meaningful learning experience. Evidence for their satisfaction about the usefulness of microteaching can be extracted from their recurrent detailed recollection and the comparison they tried to make between the two mini sessions.

In a study about reflection, Seferoglu (2006) examined the reflections of 176 ESL prospective teachers at Ankara's Middle East Technical University in Turkey on the methods of teaching and the clinical aspects of the English education program. A qualitative approach was employed for conducting the study. Participants were asked to write a thorough report focusing on their view regarding both the Methods of Teaching course and the practice components of the ESL teacher education program. The students' final reports showed that they had certain expectations about the structure of the training program. One of the findings highlighted students' views about the mismatch, which sometimes existed between course materials and actual teaching practice in classrooms. Trainee teachers, thus, emphasized their needs for more opportunities to practice teaching through microteaching application.

\section{METHODOLOGY}

\section{A. Participants}

The subjects of this study were 78 female prospective English teachers enrolled in two different courses of teaching methods of English in the Faculty of Education, UAEU. However, seventeen were excluded from the results because they were absent on the day the questionnaire was conducted. Thirty students from "Teaching Methods of English to Young Learners" (Yng) participated in the study while thirty-one students were from the "Teaching Methods of English in Elementary Schools' (Elm). The first course (Yng) was a prerequisite for the second one (Elm) at the time of the study. The researcher taught one of the two sections from each course while the other two sections were taught by two other teachers. In each course, each student was required to prepare a twenty-minute mini lesson, teach it to their peers and reflect orally and in writing about their experience in conducting that lesson. The overall weight of the microteaching components made up about $30 \%$ of each course grade.

\section{B. Instruments}

Both a questionnaire and focus-group interview questions were developed and used to collect the required data. The final version of the questionnaire included 32 items organized into four themes in accordance with the purpose and research questions of the study. The questionnaire was developed and refereed by a number of university teachers including ESL specialists in the Faculty of Education in UAEU in order to establish its validity. It used a five-point Likert scale extending from five (strongly agree) to one (strongly disagree). The Cronbach Alpha Formula was used to 
compute the reliability of the questionnaire and the value was found to be 0.91 . The questionnaire initially included forty-two items, which were later revised and reduced to 32 in accordance with the referees' comments and suggestions. The focus-group interview questions were also developed and refined by the researcher with the help of other teacher trainer specialists in the Faculty of Education in the UAEU. A number of questions were first developed and submitted to some of those teachers who participated in referring the questionnaire in order to check their suitability to provide valid support for the data collected via the questionnaire. At a later stage, ten questions were chosen after they were reviewed in accordance with the referees' suggestions and comments. An open-ended question was placed at the end of the list to allow students to add more information and express their thoughts freely.

\section{Data Collection}

Data were collected towards the end of the fall semester of the academic year 2009-2010 from student teachers in two courses of teaching methods of English (Teaching Methods of English to Young Learners and Teaching Methods of English in Elementary Schools) in the Faculty of Education, UAEU. The reason for conducting the study near the end of the semester is that by that time students would have finished all their mini-lesson sessions and they would have gone through all the microteaching experiences in both courses. Each course included two sections, one taught by the researcher. Sixty-one questionnaires (Yng. 30 and Elm. 31) were distributed to students in the four sections during class time and collected from all participating students on the same day.

After conducting the questionnaire with students in the four sections, focus-group interview sessions were organized and conducted by the researcher with the help of some students in each section. Only students in the two sections taught by the researcher participated in the focus-group interview. The reason for choosing these two sections is that all students from these two sections (49) participated in the questionnaire (Yng. 22 \& Elm.27). Students in each section were organized into focus-groups of four or five students, and a leader was assigned for each group. An intensive training session had been conducted to all group leaders to explain how to conduct the interviews with their colleagues. A mock focus-group interview session had been conducted with the group leaders to give them chance to practice the task. Later, each group leader was given a list of the questions and was asked to interview other students in the group with the help of the teacher. The reason for involving students in interviewing their peers was that prospective teachers were expected to be more open and to speak more freely if they were interviewed by their colleagues. All interviews were conducted over two classes in each section in order to give the researcher enough time to monitor the work of the group leaders. Besides the group leaders' interviews with students, the researcher interviewed two groups from each section.

\section{Data Analysis}

Both quantitative and qualitative data analyses were conducted in order to better understand the students' perspectives regarding microteaching applications in the two courses of methods of teaching English. In order to analyze the quantitative data collected by the five-point Likert scale questionnaire, the SPSS program was utilized to obtain different types of descriptive statistics and independent sample t-tests. A qualitative data analysis technique was used to look at the data collected via the focus-group interviews, specifically the Content Analysis Method (Ross 1989). A framework was created to categorize the data into patterns or themes consistent with the purpose and/or research questions of the study (Denzin and Lincoln, 1994). Following a qualitative analysis technique suggested by Patton (2002), the researcher looked at "the details and specifics of the data to discover important patterns and themes and interrelationships" (p. 41). The main reason for using this technique is to ensure that the obtained recurrent patterns and/or themes meet the requirements of the research questions and/or the purpose of the study. Later, those recurrent patterns and/or themes extracted from the qualitative data were utilized to support the quantitative data obtained from the five-point Likert scale questionnaire (Creswell, 2003). The analysis mainly focused on the prospective teachers' perspectives on microteaching applications.

\section{LIMITATIONS}

This study dealt only with female ESL student teachers but future studies that include male participants may generate data that are more diverse. The students' responses to some of the items might have been affected by assuming that their microteaching grade could be partially based on the kind of answer they provided. In spite of the aforementioned limitations, this study made some crucial contributions to better understand and improve certain aspects of ELT teacher education programs in situations where microteaching application is considered new.

\section{RESULTS AND DISCUSSION}

The overall purpose of this study was to examine prospective teachers' perceptions regarding the application of microteaching in two courses of teaching methods of English. The results of the study were analyzed under the four research questions. Analysis to the answers of question 1 (How does microteaching impact ESL student teachers' views about language improvement and course satisfaction?) showed that students were very positive about the effect of microteaching practices on their language and on their increasing enthusiasm towards the teaching methods courses (see table 1). The focus-group interview results also confirmed students' positive attitudes towards microteaching. A number 
of them (29) enthusiastically expressed their intention to continue participating in microteaching activities. The overall mean scores ranged from 4.28 to 4.61 on a 5-point scale ranging from strongly agree " 5 " to strongly disagree " 1 ". This result indicated that students in both groups felt that microteaching experience helped them improve their language proficiency and that they appreciated the usefulness of the methods courses. Nearly half of the students in the first group (Yng) thought that microteaching offered opportunities to refine their language especially the jargon used for giving classroom instruction and/or direction. When they were asked during the focus-group interview, students from both groups indicated, "microteaching experience helped us learn some useful words we need in the classroom for giving instruction and managing the classroom activities. We are happy that we learned these words before we take our 'teaching practice' next year. We learned some of these words in other courses or from teachers but we forgot them because we did not use them at all'. Benton-Kupper (2001) reported results in accordance with the findings of this study. Students viewed microteaching as an effective learning tool that enabled them to discover and develop their language ability. Ogeyik (2009) also highlighted the importance of microteaching practices in developing prospective teachers' language skills. It was argued that teacher trainees might recognize and learn to use the language effectively while they were involved in conducting mini-lessons with their colleagues. Again, ESL teacher trainees are not only learning how to teach, but they are also still developing their own English skills.

Feedback and comments given by other peers in post-teaching discussion sessions might also positively contribute to the development of student teachers' language skills. In a study about the impact of peer-coaching, Britton and Anderson (2010) showed that peer coaching practice was well-liked by students who altered their pedagogical practices as a result of being involved with other trainees in a cooperative teaching activity. The t-test showed that there are not any significant differences between the mean scores of all variables under the category of 'language improvement and course satisfaction'. The mean scores for the first group (Yng) ranged from 4.23 to 4.73, while for the second group (Elm) they ranged from 4.13 to 4.61 . For some variables, the difference was very close, such as the one about 'learning different teaching methods'. Both groups agreed that microteaching experience helped them learn and implement the methods they learned in the program. This result provides evidence that prospective teachers consider microteaching a valuable opportunity to try the different instructional theories they learned in different courses about teaching ESL. Thus, the benefits of microteaching justify its use and why it is well-liked by prospective teachers.

When comparing the mean scores of the two groups, results sometimes showed that there was a little difference between them. These differences might be attributed to the sequence of the two courses. For instance, the mean scores for the variable 'microteaching allowed me to apply ideas I learned from different courses' were 4.23 and 4.45 for the first and second group respectively. This difference might be attributed to the fact that the first course (Yng) is a prerequisite for the second one (Elm). Students in the second group would have taken and finished many courses by the time they were enrolled in the second course (Elm). This result indicated that students implemented ideas they learned in other courses in their microteaching experience. Data from the focus-group interview supports this result as about twelve students thought that mini-lesson experiences allowed them to practically use ideas they had previously learned in other courses. Some students from the second group (Elm) stated, "microteaching often allows us to use information and theories we learned in the College of Education and the College of Humanities and Social Sciences. We are happy to take this course because it helps us use what we learned in other courses".

Microteaching practice was found to provide students not only with opportunities to practice and learn pedagogical strategies but also to develop language skills (Ogeyik, 2009). Again, the mean scores of the variable about 'vocabulary improvement' were 4.43 and 4.13 for the first and second group respectively. This difference may be related to the language proficiency of the two groups. Students in the second group might have already spent three or four years in the university while the first group might have spent only one or two years there. This result might be understood in relation to the amount of exposure to English language in the university where English language is the medium of instruction. During the focus-group interview, some students from the first course (Yng) stated, "microteaching experience offered us opportunities to use the language to teach our colleagues. We also learned how to use words correctly and our colleagues sometimes helped us with this correction". In an earlier study within the same context of the present study, Author (2010) indicated that UAEU's students, including student teachers, face serious language problems when conducting different academic tasks in their programs of study. A grammar model was developed and used to help students promote effective language use. Similarly, microteaching experiences in the present study might provide prospective teachers with opportunities to recognize and learn how to use English language communicatively while they were conducting their mini-lessons to their peers. 
TABLE 1.

LANGUAGE IMPROVEMENT AND COURSE SATISFACTION

\begin{tabular}{|c|c|c|c|c|c|}
\hline \multirow{2}{*}{ Variables } & \multirow{2}{*}{$\begin{array}{l}\text { Overall } \\
\text { Mean }\end{array}$} & \multicolumn{2}{|c|}{ Mean } & \multirow{2}{*}{$T$-test } & \multirow[t]{2}{*}{ Sig. } \\
\hline & & Yng & EIm & & \\
\hline \multicolumn{6}{|l|}{ Microteaching: } \\
\hline helped me develop confidence in my speaking ability. & 4.61 & 4.67 & 4.55 & .786 & .435 \\
\hline helped me learn to speak clearly. & 4.48 & 4.60 & 4.36 & 1.38 & .172 \\
\hline encouraged me to develop my vocabulary. & 4.28 & 4.43 & 4.13 & 1.50 & .138 \\
\hline allowed me to apply ideas I learned from different courses. & 4.34 & 4.23 & 4.45 & -1.05 & .299 \\
\hline encouraged me to work harder. & 4.67 & 4.73 & 4.61 & .750 & .457 \\
\hline raised my motivation in the present methods course. & 4.46 & 4.43 & 4.48 & -.26 & .799 \\
\hline helped me to better understand different teaching methods. & 4.46 & 4.47 & 4.45 & .09 & .936 \\
\hline helped me discover and fix my language problems. & 4.43 & 4.27 & 4.58 & -1.68 & .098 \\
\hline
\end{tabular}

Results of question 2 (How do ESL trainee teachers perceive microteaching to impact their teaching competence?) demonstrated that students teachers believe that microteaching played a key role in promoting their teaching competence and making them aware of their pedagogical skills (see table 2). Overwhelmingly, students in both groups agreed that microteaching experience helped them discover their teaching strengths and weaknesses. The mean scores for this variable were 4.71 and 4.68 for the first and second group respectively. This result provided evidence that student teachers enjoyed the microteaching experience and found it to be beneficial as a training tool. Similarly, during the focus-group interview, nearly half of the students in each group asserted that microteaching offered them real opportunities to learn about their own strengths and weaknesses. Students indicated, "what we like about microteaching is that it helped us discover our strengths and weaknesses. Our friends' and teacher's feedback and comments at the end of the session drew our attentions to them. Sometimes, we felt embarrassed when we were criticized in front of our friends, but we learned from it and now we like it. I think now everyone likes it". A similar result was reported by Benton-Kupper (2001) about students' positive perceptions towards microteaching experiences. Students indicated that microteaching experience was an enjoyable experience as it offered them opportunities to increase self-confidence in discovering and enhancing their teaching skills and language ability. Similarly, Butler (2001) reported that student teachers viewed microteaching as a highly beneficial activity, preparing them for the 'real classroom' practice. In addition, in a relevant study about the effect of microteaching application on preservice teachers' competency levels, Karckay and Sanli (2009) reported a result confirming that microteaching may affect students' teaching competency.

Observing other students teaching was considered a valuable experience for trainee teachers to learn from each other (overall mean score, 4.60). Data from the interviews confirmed that students were comfortable listening to each other's comments and feedback, and this experience helped them learn from other students. This might indicate that students feel more comfortable when they work with other students who possess nearly the same level of language proficiency and teaching experiences. Some students from both groups stated, "we like our friends' comments and feedback very much because we feel that they are telling us how we are doing in our microteaching class. We also enjoy helping our friends and giving them more comments. Some students did not say anything about our teaching but we listened to other students' comments". Also, this finding gave a hint that peer-coaching is a favorable learning experience. An anecdotal result in Fry \& Hin's (2006) study revealed that peer coaching made prospective teachers feel more comfortable, confident and relaxed. It is appreciated by student teachers because it generates serious discussion, which is considered as a valuable source for promoting effective teaching strategies (Feiman-Nemser 2001). The practice of peer-coaching was found to be beneficial in different ways. Lu (2010) argued that peer coaching offers student teachers with the necessary support to develop their instructional as well professional skills.

TABLE 2.

TEACHING PRACTICE COMPETENCE AND AWARENESS

\begin{tabular}{|c|c|c|c|c|c|}
\hline \multirow{2}{*}{ Variables } & \multirow{2}{*}{$\begin{array}{l}\text { Overall } \\
\text { Mean }\end{array}$} & \multicolumn{2}{|l|}{ Mean } & \multirow{2}{*}{ T-test } & \multirow{2}{*}{ Sig. } \\
\hline & & Yng & Elm & & \\
\hline \multicolumn{6}{|l|}{ Microteaching: } \\
\hline helped me develop awareness of my teaching competence. & 4.43 & 4.37 & 4.50 & -.795 & .430 \\
\hline helped me develop the actual teaching skills I'll need later. & 4.51 & 4.50 & 4.52 & -.096 & .924 \\
\hline gave me an opportunity to learn by observing others. & 4.60 & 4.57 & 4.63 & -.334 & .739 \\
\hline made me aware of what makes a good teacher. & 4.59 & 4.63 & 4.55 & .561 & .577 \\
\hline gave me a valuable opportunity to apply my teaching skills. & 4.46 & 4.57 & 4.36 & 1.34 & .185 \\
\hline encouraged me to develop autonomy. & 4.00 & 4.30 & 4.07 & 1.29 & .204 \\
\hline helped me discover my teaching strengths and weaknesses. & 4.71 & 4.75 & 4.68 & .511 & 611 \\
\hline
\end{tabular}

The analysis of question 3 results (How do ESL trainee teachers view microteaching in relation to their managerial and preparation skills?) demonstrated that student teachers felt that microteaching experiences assisted them to enhance both managerial and preparation skills (see table 3). The mean scores for the variable concerning 'the development of materials' were 4.66 for the first group (Yng) and 4. 67 for the second group (Elm). These close high mean scores demonstrated the positive impact of microteaching on students' views about their teaching competency. Also, the overall mean scores for 'lesson planning and writing performance objectives' (4.57 \& 4.59) clearly demonstrated that students felt that conducting a mini lesson provided them with valuable experiences to learn to write comprehensible 
lesson plans and performance outcomes. These results highlighted the importance of microteaching in providing students with opportunities to try to apply the teaching strategies that they learned in different courses. They also demonstrated students' eagerness to see how the theories can work for them when they practice the craft of teaching.

Evidence from the literature demonstrated that prospective teachers thought that microteaching was a worthwhile learning experience because it helped them bridge the gap between theory and practice, learn collaboratively, develop self-reflective strategies and appreciate colleagues' feedback (Britton and Anderson, 2010; Amobi and Irwin, 2009; Fernandez and Robinson, 2007; Benton-Kupper, 2001). Participants in Fernandez's and Robinson's (2007) study pointed out that 'microteaching lesson study' (MLS) provided them with opportunities to bridge the gap between theory and practice and to develop reflective learning strategies. In the present study, a number of students (16) stated that microteaching provided them with practical experiences to learn effective classroom management procedures, lesson planning and time management. These students stated, "we learned about classroom management. We learned how to respond to students' questions and how to deal with noisy students during the lesson. Getting comments from the teacher about our lesson plan helped us correct our mistakes and write a good lesson plan at the end". A supportive evidence for this finding can be found in Fernandez's (2010) study that indicated that student teachers were able to identify general teaching patterns and classroom management issues during the MLS lessons though they were teaching their colleagues and were acting in a "fake" situation.

TABLE 3.

PREPARATION AND MANAGEMENT

\begin{tabular}{|c|c|c|c|c|c|}
\hline \multicolumn{6}{|c|}{ О КЕРАКАТІИ } \\
\hline \multirow{2}{*}{ Variables } & \multirow{2}{*}{$\begin{array}{l}\text { Overall } \\
\text { Mean }\end{array}$} & \multicolumn{2}{|c|}{ Mean } & \multirow{2}{*}{ T-test } & \multirow{2}{*}{ Sig. } \\
\hline & & Yng & Elm & & \\
\hline \multicolumn{6}{|l|}{ Microteaching: } \\
\hline helped me learn to organize my time. & 4.51 & 4.53 & 4.48 & .295 & .769 \\
\hline helped me learn how to manage the class. & 4.51 & 4.57 & 4.45 & .664 & .510 \\
\hline offered me a practical opportunity to teach a lesson. & 4.50 & 4.55 & 4.45 & .646 & .521 \\
\hline gave me an opportunity to improve my lesson planning. & 4.57 & 4.60 & 4.55 & .310 & .757 \\
\hline helped me write good performance objectives. & 4.59 & 4.60 & 4.58 & .122 & .904 \\
\hline encouraged me to develop teaching activities and materials & 4.66 & 4.67 & 4.65 & .138 & .891 \\
\hline helped me learn how to predict classroom problems. & 4.07 & 4.07 & 4.07 & .011 & .991 \\
\hline helped me learn to use technology appropriately. & 4.28 & 4.33 & 4.23 & .497 & .621 \\
\hline
\end{tabular}

Results of question 4 (What kind of attitude or feeling do teacher trainees hold about the practice of microteaching?) highlighted student teachers' positive views about microteaching applications in their program of study (see table 4.). Data collected from the interview sessions provided evidence that students in the methods of teaching English courses possessed positive attitudes towards microteaching applications. A large number of students (32) in both groups indicated that they appreciated the beneficial experiences that they gained from microteaching. Students from both groups asserted, "microteaching is very useful for our career. We learned many things about teaching. We tried our ideas and we enjoyed this experience very much. We spent a lot of time preparing for our teaching assignment, but now we feel we learned from it. We won't be afraid of teaching when we do our 'teaching practice' next year with small children in schools". Ogeyik's (2009) findings were similar to this result as they highlighted the positive views of student teachers towards microteaching applications. Students in Ogeyik's (ibid) study asserted that they appreciate microteaching experiences because they helped them develop professional skills, self-reflection, self-confidence and material selection criteria. Other studies also reached the same findings regarding the positive views of prospective teachers towards the benefits of microteaching (Fernandez and Robinson, 2007; Benton-Kupper, 2001). The aforementioned last two studies concluded that incorporating microteaching into preservice teacher training programs is highly appreciated by prospective teachers. Student teachers in both studies indicated that the hands-on experience opportunities enabled them to develop self-reflective skills, gain knowledge and promote effective teaching strategies.

Table 4 showed two main significant results relevant to students' concerns about their microteaching task evaluation. These two results indicated that students continually think about the grades that supervisors would give for their performance in the mini lessons. The mean scores for their concerns about 'lesson planning assessment' were 3.07 for the first group (Yng) and 3.94 for the second group (Elm), while the mean scores for their concerns about 'mini lessons evaluation' were 2.70 and 3.90 for the first and second group respectively. The significant differences in these results highlight the students' anxiety and the amount of time they spent in thinking about microteaching assessment during the processes of planning and executing their mini lessons. These significant results might also be interpreted in relation to student teachers' preconceptions about their teaching and/or language competence and their microteaching grades. The number of years they spent in the program and their experiences with microteaching might have contributed to the significance differences in the views of the two groups about 'lesson planning assessment' and 'mini lessons evaluation'. Generally, students bring their academic experiences and expectations to the classroom and they are, to some extent, expecting teachers to comply with them. Initially, educators and teacher trainers should try to understand what preconceptions student teachers are bringing with them to their microteaching experiences in order to help them acquire essential instructional knowledge and enhance effective teaching techniques (Butler, 2001). Another study by Amobi and Irwin (2009) also provided evidence that students in teacher training programs have some kind of knowledge about the art of teaching gained by different means. Observing teachers teaching them for many years 
allowed them to develop some conceptions about the art of teaching. Additionally, these experiences might help them start developing their identity as both students and teachers. Researchers have paid some attention to prospective teachers' experiences regarding the process and ways in which their conceptions and/or identities as teachers start to emerge and develop (Hong, 2010; Yaman, 2010; Ogeyik, 2009; Bell, 2007; McNamara, Roberts, Basit and Brown, 2002). One of Ogeyik's (2009) concluding statements was that microteaching experiences might play a key role in developing prospective teachers' professional identity in preservice education programs. Thus, student teachers developed their peculiar teaching conceptions and/or identities through their actual involvement in both executing mini lessons with their peers and observing their peers teaching.

TABLE 4.

ATTITUDES AND PERSONAL FEELING

\begin{tabular}{|c|c|c|c|c|c|}
\hline \multicolumn{6}{|c|}{ ATTITUDES AND PERSONAL FEELING } \\
\hline \multirow{2}{*}{ Variables } & \multirow{2}{*}{$\begin{array}{l}\text { Overall } \\
\text { Mean }\end{array}$} & \multicolumn{2}{|l|}{ Mean } & \multirow{2}{*}{$T$-test } & \multirow[t]{2}{*}{ Sig. } \\
\hline & & Yng & Elm & & \\
\hline \multicolumn{6}{|l|}{ Microteaching: } \\
\hline was carried out in an artificial environment. & 3.66 & 3.63 & 3.68 & -.148 & .883 \\
\hline resulted in neglecting key activities in the methods course. & 3.18 & 3.37 & 3.00 & 1.217 & .229 \\
\hline consumed a lot of my time. & 3.26 & 3.23 & 3.29 & -.194 & .847 \\
\hline made me feel bored. & 2.05 & 1.93 & 2.16 & -.737 & .464 \\
\hline forced me to do difficult tasks. & 2.90 & 2.57 & 3.23 & -1.913 & .061 \\
\hline was time limited and controlled. & 3.61 & 3.37 & 3.84 & -1.591 & .117 \\
\hline made me feel embarrassed when teaching my colleagues. & 2.72 & 2.47 & 2.97 & -1.563 & .123 \\
\hline forced me to think of the evaluation criteria while planning. & 3.51 & 3.07 & 3.94 & -2.918 & .005 \\
\hline forced me to think of the evaluation criteria while teaching. & 3.31 & 2.70 & 3.90 & -3.869 & .000 \\
\hline
\end{tabular}

\section{RECOMMENDATIONS}

This study's results emphasized certain key elements about the application of microteaching experience in preservice teacher training programs. Hence, a few suggestions and implications may be discussed within the framework of these results. First, the microteaching component should continue to be integrated with courses of teaching methods of English in pre-service teacher education programs in colleges and/or universities. The logic for its inclusion is that the microteaching experience is well-liked and highly appreciated by a number of student teachers taking the Methods of Teaching English courses. Second, more microteaching sessions should be organized and aligned with different teaching strategies and/or language skills. Third, teacher trainers and educators should pay more attention to students' views and concerns regarding their performance assessment for executing mini lessons. Students usually possess some preconceptions about the art of teaching and the methods of evaluation because those students have been sitting in classes for more than 14 years observing teachers using a variety of teaching methods to teach them. Finally, more research work is needed to look at issues highlighted by the results such as the issue of assessing students teachers' performance during microteaching sessions.

\section{CONCLUSION}

This study looked at the impact of microteaching experiences on the views of prospective teachers in an ESL preservice education program. It mainly focused on the salient concepts that emerged as a result of executing mini-lessons to colleagues in simulated situations. A mixture of quantitative and qualitative approaches was utilized to collect relevant data from two groups of ESL teacher trainees who were taking two different courses in teaching methods of English. The overall results of this study demonstrated that the inclusion of microteaching in teacher training programs is viewed to have positive impact on ESL student teachers' awareness and views regarding their language and teaching competencies. The data provided clear evidence that prospective teachers appreciated the beneficial experiences of microteaching in developing effective instructional strategies. The overwhelming benefits of microteaching justify its use and why it is well-liked by prospective teachers. A significant result highlighted students' concerns about the issue of assessing their microteaching performance. This finding stressed the need for conducting further studies to investigate the issue of assessing students' performance during microteaching sessions. Future studies should specifically focus on students' preconceptions and/or predetermined criteria for assessing microteaching experiences in ESL teacher education programs.

\section{REFERENCES}

[1] Akalin, S. (2005). Comparison between traditional teaching and microteaching during school experience of student teacher. Euroasian Journal of Educational Research, 20, 1-13.

[2] Amobi, F. A. (2005). Pre-service teachers' reflectivity on the sequence and consequences of teaching actions in a microteaching experience. Teacher Education Quarterly, 32(1), 115-128.

[3] Amobi, F. A., and Irwin, L. (2009). Implementing on-campus microteaching to elicit pre-service teachers' reflection on teaching actions: Fresh perspective on an established practice. Journal of the Scholarship of Teaching and Learning, 9(1), 2734.

[4] Author. (2010). ESP students' views of ESL grammar learning. GEMA Online Journal of Language Studies, 10(3), 143-156. 
[5] Bell, N. (2007). Microteaching: What is it that is going on here?.Linguistics and Education, 18, 24-40.

[6] Benton-Kupper, J. (2001). The microteaching experience: Student perspectives. Education, 121(4), 830-835.

[7] Britton, L. R., and Anderson, K. A. (2010). Peer coaching and pre-service teachers: Examining an underutilized concept. Teaching and Teacher Education, 26(2), 306-314.

[8] Butler, A. (2001). Pre-service music teachers' conceptions of teaching effectiveness, microteaching experiences and teaching performance. Journal of Research in Music Education, 49(3), 258-272.

[9] Creswell, J.W. (2003). Research design: Qualitative, quantitative, and mixed methods approaches. Thousand Oaks, CA: Sage Publications.

[10] Cruickshank, D. R., et al. (1996). Preparing America's Teachers. Bloomington, IN: Phi Delta Kappa.

[11] Denzin, N., and Lincoln, Y. (Eds.). (1994). Handbook of qualitative research. Thousand Oaks, CA: Sage Publications.

[12] Feiman-Nemser, S. (2001). From preparation to practice: designing a continuum to strengthen and sustain teaching. Teachers College Record, 103(6), 1013-1055.

[13] Fernandez, M. L. (2010). Investigating how and what prospective teachers learn through microteaching lesson study. Teaching and Teacher Education 26(2), 351-362.

[14] Fernandez, M. L., and Robinson, M. (2007). Prospective teachers' perspectives on microteaching lesson study. Education, 127(2), 203-215.

[15] Fry, J. M., and Hin, M. K. T. (2006). Peer coaching with interactive wireless technology between student teachers: Satisfaction with role and communication. Interactive Learning Environments, 14(3), 193-204.

[16] Grossman, P., and McDonald, M. (2008). Back to the future: directions for research in teaching and teacher education. American Educational Research Journal, 45, 184-205.

[17] Higgins, A., and Nicholl, H. (2003). The experiences of lecturers and students in the use of microteaching as a teaching strategy. Nurse Education in Practice, 3( 4), 220-227.

[18] Hong, J. Y. (2010). Pre-service and beginning teachers' professional identity and its relation to dropping out of the profession. Teaching and teacher Education, 26(8), 1530-1543.

[19] Johnson, K.E. (2006). The sociocultural turn and its challenges for second language teacher education. TESOL Quarterly, 40, 235-257.

[20] Karckay, A. T., and Sanli, S. (2009). The effect of microteaching application on the pre-service teachers' teacher competency levels. Procedia Social and Behavioral Sciences, 1(1), 844-847.

[21] Kubukcu, F. (2010). Congruence and dissonance between micro-teaching and macro- teaching. Procedia Social and Behavioral Sciences 2(2), 326-329.

[22] Lu, H. L. (2010). Research on peer coaching in pre-service teacher education: A review of literature. Teaching and Teacher Education 26, 748-753.

[23] McNamara, O., Roberts, L., Basit, T., and Brown, T. (2002). Rites of passage in initial teacher training: Ritual performance, ordeal and numeracy skills test. British Educational Research Journal, 28(6), 863-878.

[24] Ogeyik, M. C. (2009). Attitudes of the student teachers in English language teaching programs towards microteaching technique. English Language teaching, 2(3), 205-212.

[25] Patton, M. Q. (2002). Qualitative research and evaluation methods (3rd ed.). Thousand Oaks, CA: Sage Publications, Inc.

[26] Putnam, R. T., \& Borko, H. (2000). What do new views of knowledge and thinking have to say about research on teacher learning. Educational Researcher, 29(1), 4-15.

[27] Ross, D. D. (1989). First steps in developing a reflective approach. Journal of Teacher Education, 40, 22-30.

[28] Seferoglu, G. (2006). Teacher candidates' reflections on some components of a pre-service English teacher education program in Turkey. Journal of Education for Teaching, 32(4), 369-378.

[29] Subramaniam, K. (2006). Creating a microteaching evaluation form: The needed evaluation criteria. Education, 126(4), 666677.

[30] Wilkinson, G. (1996). Enhancing microteaching through additional feedback from preservice administrators. Teaching and Teacher Education, 12(2), 211-221.

[31] Yaman, S. (2010). Conceptual change of pre-service teachers: A longitudinal action research study in ELT. Procedia Social and Behavioral Sciences 3, 227-236.

Sadiq Abdulwahed Ahmed Ismail obtained his Ph.D. Degree in English Language Education (1997) from the Department of Curriculum and Instruction, College of Education, Florida State University, Tallahassee, Florida, United States of America and his MA. Degree in TESOL and Linguistics (1989) from Moray House College of Education, Edinburgh, Scotland, United Kingdom. He has worked for different educational institutions in different countries. He is currently an assistant professor of English language education in the Department of Curriculum and Instruction, College of Education, United Arab Emirates University, Al_Ain, United Arab Emirates (2008-present). Previously, he worked in Yemen, the United States of America and the United Arab Emirates. He is a member of different professional organizations, such as Asia TEFL, TESOL Arabia, etc. The following research articles are examples of his recent publications: $\{1\}$ Sadiq Abdulwahed Ahmed Ismail (2010). ESP Students' Views of ESL Grammar Learning. GEMA Online Journal of Language Studies, 10(3), 143-156. \{2\} Sadiq Abdulwahed Ahmed Ismail, Abdurrahman Ghaleb Almekhlafi \& Mohamed Hatem Al-Mekhlafy (2010). Teachers' perceptions of the use of technology in teaching languages in United Arab Emirates' schools. International Journal for Research in Education (IJRE), 28, 37-56. Faculty of Education, UAE University. 